\section{NEW WAY, OLD PATTERN. SEASONAL MIGRATION FROM POLAND TO GERMANY}

\author{
Kamila Fiałkowska \\ University of Warsaw \\ k.fialkowska@gmail.com \\ Maria Piechowska \\ University of Warsaw \\ maria.piechowska@gmail.com
}

Cómo citar este artículo/Citation: Fiałkowska, K. and Piechowska, M. (2016). "New way, old pattern. Seasonal migration from Poland to Germany". Arbor, 192 (777): a285. doi: http://dx.doi.org/10.3989/arbor.2016.777n1001

Received: September 12th, 2013. Accepted: October 31st, 2014.

ABSTRACT: This article reviews seasonal migration from Poland to Germany from the perspective of functioning of the Polish-German agreement on seasonal work. The title calls for attention to two issues - firstly, the new agreement which was - as compared to other signed by EU member states with third countries - of outstanding relevance due to the scale of migration; on the other hand - migration that followed was well known and established among Poles. The paper suggests that seasonal migration in the state as it is today, has its roots in the distant past and concludes that development of particular migration schemes may be considered as a result of power relations and inequalities between states, which are reproduced on the actors level.

KEYWORDS: migration-Poland-Germany; seasonal workers; bilateral agreement; agriculture; migration network.

\section{MODOS NUEVOS, PATRÓN ANTIGUO. LA MIGRACIÓN ESTACIONAL DESDE POLONIA A ALEMANIA}

Copyright: $\odot 2016$ CSIC. This is an open-access article distributed under the terms of the Creative Commons Attribution-Non Commercial (by-nc) Spain 3.0 License

RESUMEN: Este artículo se detiene en la migración estacional polaca hacia Alemania a partir del análisis del funcionamiento del acuerdo polaco-alemán sobre trabajo estacional. Su título destaca dos elementos principales. El alcance numérico del nuevo acuerdo en comparación con otros acuerdos firmados por Estados de la Unión Europea y terceros países y la corriente migratoria derivada de este acuerdo. El artículo sugiere que la actual migración estacional tiene sus raíces en la historia migratoria polaco-alemana y concluye que el formato y desarrollo de este sistema de regulación migratoria puede ser considerado resultado de las desiguales relaciones de poder existentes entre Estados, que se reproducen en la esfera de los actores.

PALABRAS CLAVE: Migración Polonia-Alemania; trabajadores estacionales; acuerdos bilaterales; agricultura; red migratoria. 


\section{INTRODUCTION}

Recruitment of migrant workers has become popular in states facing the ever-changing nature of labor markets and the challenges of economic development. This is often done by signing a bilateral agreement regarding temporary workers which regulates the general conditions of entering a particular sector of the labor market, such as recruitment, time span and overall conditions of residence (Kaczmarczyk and Łukowski, 2004). In this article we aim to shed light on agreements on the recruitment of seasonal workers from Poland to Germany, which proved to be of outstanding relevance when it comes to regulating migration flow and allowing legal temporary migration from Poland to one of the EU member states as early as the beginning of the 1990s.

In the following parts of the article we want to discuss the wider context of labor migration between the two states. The first part of the paper, therefore, looks back at the past in an attempt to show the importance of the previous links and existing migration patterns or traditions which can be considered factors contributing to the future success of the scheme designed to attract seasonal workers. Then the changing socio-political situation on the eve of Poland's transition is described, followed by an explanation of the rationale behind and construction of the Polish-German agreement. These parts discuss in detail the general conditions of employment and the functioning of the system, and present the reality of seasonal migrants. The final parts of the article focus on the outcomes of this migration from various possible perspectives, although due to space limitations this vast subject cannot be exhausted and many issues are only mentioned in passing but still call for more attention and scholarly debate.

This paper is based on the desk research combined with results of research in sending and hosting communities of seasonal migrants from Poland conducted within the frameworks of the project entitled "Sociocultural effects of seasonal migration for local communities: Case Studies of Poland and Germany" realised in cooperation by Bielefeld University and University of Warsaw ${ }^{1}$. The research was conducted in Poland and Germany, using the ethnographic techniques of the social research methods such as covert participant observation in Germany among the seasonal migrants and participation in socio-economic life of sending local communities in Poland. In parts relating directly to everyday realities of migrant workers and functioning of the system authors refer to their research findings and observations (see also Wagner et al., 2013).

\section{SEASONAL MIGRATION - A GLIMPSE OF THE PAST}

Migration in order to take up short-term work in German agriculture has a long tradition in Poland. At least since mid-nineteenth century people inhabiting Polish territories, which back then were under Prussian, Russian and Austrian partition, traveled seasonally to East Prussia and Saxony, only later to reach industrial centers in the Ruhr region (Marek, 2008). From those expeditions there is a still-current phrase in Polish that describes economic activities in Germany - "jeździć na saksy" - which would mean that one is going to work in Saxony (as initially this was one of the most popular destinations), and 'saksy' itself functions as a synonym for temporary work in Germany.

By and large, seasonal migration took place among Poles inhabiting territories under German control as a result of the partition of Poland in the 18th century. This was, therefore, internal migration within the boundaries of the German Empire at the time. Those living in Russian- or Austrian-controlled areas faced restrictions in access to work in agriculture in Germany as it was feared that many of them would settle down. General policy at the time was to keep the Polish minority under control so that it would eventually assimilate, whereas the influx of Poles from the outside would put a question mark on the effects of this policy. Nevertheless, it soon became clear that demand from German farmers was growing, especially since a considerable number of workers (both of Polish and German nationality) had eventually moved to work in growing industries in the Ruhr region. Therefore, in 1912, of nearly 600,000 workers, half were from outside the German Empire, and the number was allocated according to the demand of farmers (Landau, 1966). After World War I, the temporarily suspended circular migration returned to its previous form. However, soon after this migration policies took a more restrictive turn due to the Great Crisis. This policy was later continued by the Third Reich, not only for economic reasons, but also ideologically - recruitment of a foreign labor force was not welcome. Only in the second half of the 1930s was recruitment of Poles resumed due to labor shortages and investments in heavy industry (Landau, 1966). From the Polish point of view, especially during the interwar period, the possibility of migration of Polish nationals to their western neighbours was highly desirable. This was due to various reasons - the young Polish state, re-established in 1918, was struggling with many problems, of which huge unemployment was one of the most persistent and difficult to deal with, therefore it put considerable 
effort into providing access for Poles to foreign labor markets through bilateral agreements with respective states (Kicinger, 2005).

The time of World War II was exceptionally different. The Third Reich used forced labor in many branches of the German economy, including agriculture, to ensure undisturbed production and avoid labor shortages during war time. The war and its aftermath also changed the migratory situation between two states and put a halt to economic migration from Poland for decades to come. The fast-developing economy in post-war West Germany quickly experienced labor shortages. Therefore, to minimize production costs, recruitment from abroad was seen as viable option to achieve the goals of economic development. Moreover, the pool of jobs which locals were unlikely to undertake was growing, which called for one of two options - either to increase the earnings of the locals or to recruit workers whom they could pay less. This called for recruitment of workers from other parts of the world - therefore respective agreements were signed with Turkey (1961) and Yugoslavia (1968), among others. Some sectors of industry, much like agriculture, were, to a great extent, relying on the work of newcomers. Geographical proximity and the changing political and economic situation in Poland, alongside German demand for workers, were some of the many reasons why seasonal migration soon re-emerged on the migration landscape of Poland and Germany.

\section{FROM SHUTTLE MIGRANTS TO SEASONAL WORKERS}

With the decreased control of the Polish socialist state over its borders and increasing economic crisis in the late 1970s and 1980s in Poland, the government relaxed the visa regime, allowing its population freer crossings of the western borders. The times of 1970s and 1980s where the economic crisis was more severe in Poland were also the beginning of increased shuttle migration, which, in Polish migration literature, has been dubbed a phenomenon of "incomplete migration" (Jaźwińska-Motylska and Okólski, 2001). Its origins lie in unfinished urbanization, which means that during socialist development and industrialization the infrastructure of the cities was not developed enough to accommodate thousands of workers from rural areas. It was cheaper to keep them living where they were and to subsidize transport to the factories or hotels than invest in the construction industry. Those people were usually of lower skills and education, therefore their wages were less than the other workers. Furthermore, they could complement their wages with the harvests from their land, which usually most of them had. However, at the time of crisis they were the ones who were first to lose their jobs - due to cuts in transportation and temporary housing their low qualifications made them redundant. Lastly, living in a village without a job they would supposedly still be better off than those who lived in cities. Among many who then went on the road to Germany were those from small towns and villages, who could not find employment in their local area, and moving permanently to the big cities was beyond their financial capacity. When the visa system was relaxed they saw their chance of making a living by crossing the border, selling goods, for which they could get better prices abroad, or searching for work in low-skilled sectors - i.e. in agriculture. Numbers soon increased and since the late 1980s seasonal migration has again become one of the numerically most important labor migration flows from Poland (Kaczmarczyk and Łukowski, 2004; Kępińska, 2008; Marek, 2008).

Migration from Poland to Germany in the late 1980 s and early 1990s was mainly circular in contrast to the general trend of European migration, which was rather of a permanent character (cf. Jaźwińska-Motylska and Okólski, 2001; Kaczmarczyk and Łukowski, 2004; Morokvasic, 2004). Among others, Mirjana Morokvasic (2004) emphasizes that Poles in the last decade of socialism and especially after the transition (1989) were relatively free not only to leave the country, but also to return to it, which was a novelty since for many decades emigration was strictly controlled and maneuvered by the government to achieve specific political or economic gains (i.e. expulsions of ethnic Germans, further emigration of people of German descent, emigration of Jews - these were the only exceptions in an otherwise restrictive migration regime, Stola, 2010). This freedom was especially important during the transition period that started in 1989 and which proved to be very difficult in terms of economy and job loss - many were forced to diversify their economic behaviour, which often meant labor migration abroad. At the same time, however, freedom to leave Poland was not followed by freedom of settlement abroad. Therefore, circular and repetitive in nature, migration was not just a matter of choosing this particular form of migration, but often a necessity. Due to the differences in wages and prices between Germany and Poland, this kind of mobility has proved to be profitable for many years. 


\section{BILATERAL AGREEMENTS OF THE 1990S}

Socio-political changes in Europe after the fall of the Iron Curtain created an opportunity to sign bilateral agreements related to labor migration between countries of Western Europe and those from the former communist bloc. Very quickly, on $8^{\text {th }}$ December 1990 , the Polish and German Ministers of Labor released a joint statement on the possibility of employment of Polish workers in Germany. The statement determined the pattern of migration in the coming years and for a long time was indeed the only really functioning and significant bilateral document considering labor migration to Germany. ${ }^{2}$ From the collapse of the old system until 2001 the Polish government signed a total of 18 agreements with 15 European countries regarding migrant workers. Those were not very popular or the requirements were too high, so that only a few people migrated on the basis of them, and some agreements did not work at all (Okólski, 2004a, pp. 24-25). The statement of 1990 widened the access of Poles to the German labor market and was the most important act signed between the two states regarding labor migration. The agreement functioned alongside previously signed agreements on "contract workers" (signed on 31 January 1990), and "guest workers" (signed on $7^{\text {th }}$ June 1990) (Rajkiewicz, 2000, p. 33). Besides several groups of migrants from Poland, i.e. contract workers, cross-border workers (who were allowed to work no more than $50 \mathrm{~km}$ from the PolishGerman border and who were supposed to go back every day to their home country), guest workers, student workers and seasonal workers were allowed to enter the labor market for a specific length of time which was a maximum 3 months per year (Kępińska, 2008 , p. 135). It soon became apparent that (other than seasonal workers' programs) these programs were not of interest to Polish workers. An example of this lack of interest is evidenced by the fact that the number of 1,000 people which had been the limit of "guest workers" defined in the declaration, was never achieved (Okólski, 2004a, p. 25)

It took almost ten years from signing the joint Declaration of 1990 to the adoption of a Polish-German agreement dated July 8, 1999, which laid down the conditions of employment of seasonal migrants, their accommodation and defined the rules for social security (see Kępińska, 2008, pp. 181-86). Previously established procedures did not have such an official form. It is worth stressing that neither the statement of 1990, nor the 1999 Agreement were published in any official journals of legal acts: Polish Dziennik
Ustaw (Dz. U.) and German Bundesgesetzblatt (BGBI). That fact emphasizes the large scale of informality governing seasonal employment (Kępińska, 2008, p. 142). The details of the procedures and conditions that determined migration on both sides of the border were regulated by several internal bills and regulations. The most important is the Polish Act on employment of 29.121989 (Dz. U. 1989 No. 75/ 446), the Act on employment and counteracting unemployment of 14.121994 (Dz.U. 18.03 in 1997, No. 25 and. 128), and the German Law concerning the promotion of employment (Arbeitsförderunggesetz, BGBI. I, 1969, No. 51: 582, BGBI I, 1997, No. 20: 696), the Act on prohibition of recruitment of foreign labor from 11.21.1973 (Anwerbestopp, Bullietin No 151: 1506), subsequent changes in the law on work Anwerbestopprmits (BGBI I, 1990, No. 73: 3009 and BGBI I, 1993, No. 47: 1527), and the regulation defining conditions and rules for seasonal work (Dienstblatt der BA, 16/91, 04.01.1991).

Seasonal employment became an important instrument in the labor market on both sides of the border. Informality and simplicity of procedures proved to be encouraging for German employers and Polish employees, and the number of seasonal migrants has grown ever since. The statement of 1990 did not specify the branches of the economy available to Polish seasonal workers, but access was to be granted based on earlier research into the labor market. According to this, in 1993, the possibility to take up employment in the construction sector had been excluded (Kępińska, 2008, pp. 135-136). Given the short terms of employment and lack of other special requirements plus a massive demand on the German side made agriculture predestined to come out as one of the most appealing options for hundreds thousands of workers, especially when compared with other opportunities for legal employment in Germany.

It is worth quoting the preamble of the statement of 1990. Authors referred there to the agreement concluded in the previous month: on $14^{\text {th }}$ November 1990 the border between Poland and newly reunified Germany ( $3^{\text {rd }}$ October 1990) was finally confirmed after World War 2.

"By the will of both sides, the long lasting opportunities of employment of Polish workers in the Federal Republic of Germany and Germans in Republic of Poland will serve the building of European unity.

We also perceive in these opportunities the source of mutually beneficial economic cooperation and partnership. 
We are convinced that new opportunities of employment will promote business exchanges and will be a natural and lasting phenomenon in the new economic deal in Europe and in mutual relations.

Common work of Poles and Germans will be the basis of mutual rapprochement, improvement of professional skills, learning languages and being acquainted with the countries and people." (Based on the text of a statement on the basis of Kępińska, 2008, pp. 281-86, translation) ${ }^{3}$.

The opportunity of employment was supposed to be a contribution to the "new economic deal" and "rapprochement" of Poland and Germany, for decades antagonized by existing in two different economic and political blocs. Such fine words surely captured the atmosphere of joy after the collapse of the Soviet bloc, but the reasons for concluding this agreement were wider than the enthusiasm of Europe in the process of uniting. Georg K. Menz notes that in the late 1980s Germany was experiencing labor force shortages and the idea of seasonal workers was in fact the re-invented concept of 'Gastarbeiter'. He writes: "the 'new' paradigm might not be viewed as new at all, but merely old wine in a new bottle" (2001, p. 256).

The same author mentions the following five reasons why Germans were interested in recruiting a seasonal labor force from Poland. (1) The German government intended to explore new regulatory approaches towards migration from EU applicant countries. (2) Poland was also a natural partner for Germany and close bilateral relations could have helped German investments in Poland. (3) The Ostpolitik of chancellor Helmut Kohl, which was reflected in the final recognition of Polish-German border. (4) Central and Eastern European countries had already signed a bilateral treaty on exchange of labor forces with East Germany, and the Federal Government did not want to end "this relationship abruptly." (5) Lastly and most obviously, the long tradition of circular migration of Poles to Germany and back to Poland served for a long time as a reservoir of cheap labor. This meant that not only were routes to Germany already well known to Polish workers, but also a wide network of migrants was in place. These very quickly became crucial in the process of Polish seasonal migration to Germany (Menz, 2001, pp. 256-258).

The political transition in Poland entailed profound social and economic changes, and thus relatively high unemployment. The agreement with Germany has therefore been considered an instrument to fight structural unemployment. This was evidenced by a document published by the Ministry of Labor and Social Policy in April 1991 (Requirements for easing the effects of unemployment) in which seasonal work in Germany was described as one of the tools to minimize the negative effects of transformation, of which unemployment was one of the most sensitive social problems. Similarly, in 1994, one of the documents issued by the same ministry stated that "Seasonal work is considered to be a means to reduce the negative effects of unemployment" (Okólski, 2004a, p. 27). Another factor was that in the course of 1980s, many Poles undertook illegal work in Germany (as explained above), so the bilateral agreement allowed legalization of their work and thus also became a tool to fight illegal migration.

\section{FUNCTIONING OF THE SYSTEM}

From the moment of signing the respective agreements with Germany seasonal work was one of the most popular options among Poles - firstly due to restrictive criteria surrounding other groups of workers: guest-workers had very high qualifications, employment in the borderland zone (cross-border workers program) was limited to those who had a permanent address in those areas, and contract workers were people who were employed by a Polish company to be then posted to work for the German company this was used especially by the construction industry and as soon as in 1993 more restrictions were placed upon this field to protect the local workers.

Seasonal work was focused mostly around work in agriculture and gardening. Also, high geographical concentrations were to be noticed, as most of the workers were employed in the western parts of Germany, and those with relatively long traditions of agriculture and a high percentage of migrating workers in the past (such as Lower Saxony, Bayern, North Rhine-Westphalia, North Rhine-Palatinate) (Kaczmarczyk, 2005).

The number of seasonal workers in agriculture grew steadily through the 1990s and reached 300,000 in the year of Polish accession to the EU (Kępińska and Stark, 2013). As was previously the case, workers could initially only work for 3 months during one year. Later on, however, the time period was extended to 4 and then 6 months, until 2011, when the probationary period which Germany placed upon new member states in accessing their labor market passed and unrestricted access for Poles to the German labor market was granted (Dritte Verordnung zur Änderung der Arbeitsgenehmigungsverordnung, BGBI I, 2010, No. 27: 1536.). Prior this, over the last two decades, 
Poles were the largest national group among seasonal workers in the German labor market (Kępińska, 2008).

Agreement about seasonal work was demandbased and gave initiative to German employers who wished to recruit a labor force from Poland via cooperation with labor offices in both countries. Construction of the agreement allowed for recruitment in two ways - via anonymous job offers and named job offers. The procedures which were established provided that the German employer would submit a job offer to a particular employee (a named job offer) or an anonymous offer open to anybody, in particular to the residents of Polish regions with high unemployment rates. The offers had to be authorized by both German and Polish labor offices. Polish local labor offices delivered offers to specific Polish workers, or conducted recruitment in cases of anonymous offers. Authorized offers guaranteed access to special visas with work permits with a small administration fee of up to 30 Euros (depending on whether it was a single or multiple entry visa; lower prices applied to students) (Kaczmarczyk and Łukowski, 2004).

Soon it became evident that most of the offers sent to Poland were the named job offers, which were reaching specific employees, meaning that recruitment through the offices soon lost almost all importance (Kępińska and Stark, 2013). This is not difficult to understand since employers preferred to employ someone they already knew, or someone recommended to them by previous employers rather than rely on recruitment through a job center. This is for many reasons - despite the given characteristics of the work place and duties of the workers, the job center could not give any insights as to how the work was organized on a daily basis to an interested applicant, or what one would have to take along (i.e. clothes, food, etc.) and could only vaguely judge a person's ability to cope with exhausting work in the field as a result of lack of expertise in the area. In contrast, previous employees knew all this and could give useful advice related to work and relations with coworkers and employers. All these factors also encouraged would-be workers to search for those who already had worked in Germany in order to give them recommendation and eventually get the job offer from Germany, rather than go to the office and wait for an anonymous agreement and an open call to fill the position.

This situation was the major cause of recruitment mostly relying on informal networks and contacts with employers, or with the middlemen who could provide these contacts. This very much resembles the situation of the seasonal workers back in the $19^{\text {th }}$ cen- tury, where so-called immigration agents and middlemen were sent by employers to recruit workers. Over the years it became clear for many employees that in order to secure a work position they had to keep good contacts with the employer, because the nature of temporary employment meant that once those relations were under strain their contract for the next season would be at risk.

Employers gladly cooperated with those Poles they had already met - they either employed them or relied on them in searching for more workers (previous contacts made in the 1980s). The pioneers of migration were very useful in this respect, as from them the network of migrants and employers started growing. According to research (Kępińska, 2008, p. 191) more than $80 \%$ of workers knew about a position not from the press, radio or the job center, but from other persons in the migration network. This confirms the fact that the informal procedure was dominating the process of recruitment and those seeking employment were more likely to get one via contacts than via a job center.

In the course of time it became evident that some families monopolized access to specific employers for example in case of small family farms, where in the season only a dozen people were employed. Those contacts were distributed only amongst members of the family and friends. Also in many cases migration to work for this employer continued for many years and, eventually, it often happened that children of the first workers were employed there in later seasons (Piechowska and Fiałkowska, 2013, p. 181).

In many cases employers used their employees to recruit workers, not being bothered with advertising positions in Poland or with contacting the job centers - firstly this would be time consuming to them, and secondly, not necessarily effective, due to the fact that some people would fear to answer job advert in the press (due to the high risk of fraud). Therefore these tasks were shifted to employees who were to be trusted, mostly those who had worked for the farmer for a long period of time. Often those employees, acting as middlemen, demanded money for the position and the job was given only if the specific amount of money was paid to the middleman. It is enough to say that those practices are outlawed in Poland and Germany, but the assumption can be made that they were known to the employers and were tolerated by them. On the other hand people were not always aware of the fact that this practice was illegal, as for some of them this seemed to be a chance to secure a job during the season. 
The function of middlemen is, for many reasons, interesting - it seems that many middlemen were those who had double (Polish and German) citizenship (Piechowska, 2013, p. 34). Those people mostly come from Upper Silesia, Opole or Lower Silesia, as those regions previously belonged to Germany (before 1945) and still had quite a considerable percentage of the population with German descent enjoying the benefits of unrestricted work in Germany (as in Germany they were treated as German citizens). Despite the fact that they had never been a subject of bilateral agreements related to seasonal workers (since their employment was based on the same ground as any other German citizen) their economic activity was almost entirely concentrated in the secondary labor market. They could reside in Germany longer than any other seasonal worker, due to the lack of restrictions placed upon them and could build up their networks in the hosting community. On the one hand they were in a better position than any other seasonal worker, due to the fact that their work was not legally bound to a time period, nor to any specific field of the labor market. On the other hand, however, linguistic inadequacy or the family living in Poland stopped them from moving up the social ladder in Germany as this would require additional training, education and time. Therefore their position, despite having German passports, was not diametrically opposite to those without them. With time, many of them moved to work in the Netherlands, where they could work as German citizens - as Poles still were facing restrictions - mostly also in agriculture, i.e. gardening or greenhousebased jobs where higher wages were offered (Karczemski and Boer 2011).

The informality ruling seasonal employment, especially recruitment via migration networks and, to some extent, their commercialization (paying for the job offer), meant that no formal intermediaries were involved in the process of recruitment, i.e. temporary work agencies. In recent years new EU member states have helped the interests of recruitment agencies and, in Poland specifically, the rise in numbers of recruitment agencies since the 2004 has been significant (Napierała and Fiałkowska, 2012). Nevertheless, within the remit of the agencies are services such as caretakers, cleaners and builders, not to mention those relating to professions requiring higher qualifications i.e. engineers or medical staff. Due to the nature of informal recruitment for seasonal work in Germany and the temporary nature of the work, employers would not be interested in bearing the costs of recruitment via an agency, since these duties have so far been successfully handled via migration networks. It also seem very probable that in a situation of scarce migration networks in particular industries and few contacts between employers and employees in two different countries the costs of matching workers without intermediaries would be too high, therefore employees turn to official intermediaries such as agencies. In the case of seasonal employment this work has been effectively performed by middlemen and migration networks are still very effective in finding employment in agriculture, therefore this market is unattractive to agencies.

\section{GOBLINS IN THE ATTIC - BEING A SEASONAL MIGRANT}

By taking a job in German agriculture Poles are positioned in a specific situation. As "an army of goblins" (Heinzelmannerarmme), as German sociologist Jorg Becker describes them, they arrive, do their job and they go back home (Becker, 2010, p. 7). Like goblins they do work for their hosts and live in abandoned or unused parts of houses. Work is the center of their life in Germany. "We came here to work, not to take rest." This sentence is repeated over and over by workers. The time of year, the harvest, and the weather determine the rhythm and the length of their work day. It can be as long as 15 hours, or as little as only 2 .

The work is usually organized on a piecework system or is paid hourly. Obviously, the organizational system depends on the type of work and harvest period, and it has an impact on the daily life of the migrant, especially with regard to cooperation and competition with co-workers (Fiałkowska, 2013).

Sizes of farms also have an impact on how work is organized and how relations between workers themselves or between them and their employer are characterized. In bigger farms there are usually persons called "rajkowy", from the German word "die Reihe" (the row), who arranges the work and who is responsible for the quality of job. In smaller farms someone who has greater experience in working in the particular farm usually takes this role. Interestingly, language skills are usually not of great importance when it comes to determining the social hierarchy among workers - which, however, may differ according to the size of the farm. In bigger farms it does not have to have any importance for an average worker, as the group of people is usually managed by those (rajkowy, or middlemen), who have a basic command of German. In smaller farms, where hierarchy is not so stiff, it can have some importance and influence the upgrading of the position of the worker regardless of 
previous work experience in this farm. Knowledge of German is not widespread among seasonal workers, but most learned some basic words which are helpful for their work and communication with the employer. Furthermore, employers also often picked up some Polish words to make communication easier.

German employers are supposed to organize accommodation for the workers (which does not mean they do not have to pay for it). Usually it is some kind of basement, cellar or the attic in an outbuilding. In bigger farms, where the number of workers can reach the hundreds, this usually takes the form of containers. It is worth emphasizing that in the contract which seasonal migrant is supposed to sign with his employer, one can find, spelled out, the minimal conditions of accommodation which had been specified in the previouslymentioned agreement of 1999. These are: a minimum of 6 square meters per person, a maximum 6 persons in a room - women and men separately, bed and a cupboard should be provided for every person as well as a chair and place by the table, there should be a place to prepare food - minimum one kitchen stove per 2 persons, access to the fridge, one toilet per 8 persons, and one shower per 10 , access to a washing machine and access to a first aid kit. These were suggestions for newly-built accommodations as was outlined in the agreement of 1998. As light departure from these norms was tolerated. It goes without saying that not every employer complied with those requirements - containers were often too small to host six people, some workers still lived in caravans during the harvest season, the number of showers or toilets was below the required amount, there was a lack of hot water, limited or no access to the washing machine and, in extreme cases, power cuts in the accommodation of employers. These were the findings from fieldwork, and interviews with other seasonal workers confirm that these are still frequently experienced problems (Piechowska and Fiałkowska, 2013).

Due to the type of work and lack of language skills migrants are practically excluded from the life of the host community. Migrants spend most of their time working or resting, which usually means sleeping. They hardly have any opportunities to have outside contacts or relationships, if we speak in a more general way, with the host community. The host community for them usually means their farm, so the most important issue here is what kind of relation they have with their employer or their employer's family. In big farms contact with the German employer is usually severely limited - all things such as documents or payment can go through Polish middlemen. In smaller farms, however, the situ- ation can be very different so that German employers even work side-by-side with their employees (i.e. in vineyards). They usually know their workers, their families and friends. More personal and frequent contacts allow for better understanding between employers and their employees. What is more, work positions in smaller farms are often monopolized by families or groups of workers from the same area in Poland - any free positions are therefore safely guarded and distributed only among the closest circles. This also shows the significance of the migration networks and the importance of social capital, as mentioned previously in this paper. Those relationships, although based on economic benefits for both groups, may, however, lead to the occasional sending of a postcard or an invitation to visit Poland, which shows some deeper level of understanding or friendship struck up between workers and their employers (Fiałkowska and Wagner, 2013).

\section{OUTCOMES OF THE PROGRAM}

The signing of the bilateral agreement in December 1990 was an event of key importance: it opened the way for legal labor migration into German agriculture for a growing number of people, who organized their life so that it fitted the enduring temporary mobility, without permanent change of residence (Kępińska, 2008; Korczyńska, 2003). According to available statistical data, the cohort of seasonal workers from Poland in Germany consists of few hundred thousand people every year (Kępińska, 2008, p. 94). The number has been growing steadily since the early 1990s. It is remarkable, that at the time of Poland's accession to the European Union (2004) more than 300,000 people went to work in agriculture, exceeding the massive migration to the United Kingdom at the time (this is the number of registered work agreements, however numbers of those who worked without them, e.g. in the shadow economy, are probably much higher).

As to the popularity of seasonal migration, even after the EU enlargement and after more than two decades of functioning of the agreement ${ }^{4}$ of seasonal migration, it is worth considering the outcomes of this scheme. Its further success and large number of people participating in the program seem to be an outcome of many factors such as simple administrative procedures that govern the process of seasonal migration and especially recruitment procedures. Also, the low costs of migration and well-developed migrant worker networks combined with growing demand on the German side and migration pressure in Poland contributed to the spectacular success of 
this bilateral agreement. It is also worth keeping in mind that the 1990s were a time of economic downturn in many European labor markets, which, in turn, provoked more restrictive migration policies fighting illegal migration and employment practices that disfavored native workers. In this context the possibility to take up legal employment in Germany has become an appealing option for a growing number of Poles.

In the overall well-functioning bilateral agreement there is, however, a clear gap between policy and outcomes - from the Polish perspective the agreement was initially meant to function as a labor market mechanism fighting structural unemployment (Okólski, 2004a, p. 24). Significant informality in the recruitment process via migration networks and the predominance of the named job agreements meant that the practical mechanism of the functioning of the system targeted those who were in touch with someone in the migration network and not necessarily those who were unemployed in the first place. This was confirmed in further research, where it was found out that only a small percentage of the agreements reached those who were unemployed (Korczyńska, 2003, p. 129). This is also proved by geographical concentration - regions with higher numbers of seasonal workers were not necessarily those with the highest unemployment rate. Rather, these were those regions who had more intense contacts with Germany (such as Lower or Upper Silesia, and Greater Poland) and those with widely developed migration networks. As a result the government had few options in managing migration flow and influence on to whom work was actually going (Okólski, 2004b, p. 211).

An immediate outcome as regards the commencement of functioning of the system was the possibility to engage in legal work in Germany for thousands of Poles. The situation of the eighties was clearly known by the authorities of both countries (legal migration on a tourist visa and illegal work), therefore the agreement paved the way for legal employment and it was a chance that many took, despite the fact that upward social and economic mobility was rather limited and migrants were put on the margins of the labor market in Germany.

As for Germany the scheme was important mainly to manage the inflow of foreigners to those sectors of the economy which were not popular among local workers or suffered from labor shortages and which, due to high competitiveness on an international level, needed a cheap labor force to maintain its productivity. Selectivity - meaning that only few sectors of the labor market were accessible - and control over the process - especially regarding the time span one could spend working - proved to be very successful.

From a research evidence from the project "Seasonal migration as everyday practice. (...)" one issue also calls for more attention on the part of authorities in both countries and this is the average low levels of awareness of the rights that seasonal workers have and readiness to confront employers for betterment of the workers position - especially in terms of living conditions, which are often substandard but accepted as they are because workers fear that employers will shorten their contract, cut their hours or perform some other act of retaliation, such as declining to offer an invitation for the next season.

Soon, the other visible outcome of seasonal migration came to the fore - the economic remittances of the workers. Despite the fact that earnings may not be attractive for the native worker, earning an average of 5 Euros per hour made it possible for many to accumulate a sum of a few thousand Euros at the end of the harvesting season (by working more extensively when paid by the unit, or working more than 8 hours per day $)^{5}$. Those sums were usually spent on investments aimed at improving standards of living - i.e. the building of a new house, renovation, a new car, etc. This material evidence of economic prosperity was also a significant sign of upward social and economic mobility in the local community, maintaining the image of a successful migrant and had a positive impact on enhancing migration from a particular area.

Seasonal migration may be time-limited (a few months per year), however its repetitive nature and only slowly improving situation in the local labor markets in Poland, plus long-term investments that many of them undertook, meant that for many workers episodes of seasonal work have become circular and repetitive over many years. This allowed them to accomplish some of their projects, i.e. renovating the house, earning money for the weddings of their children, or supplementing family incomes while the children were still at school or studying. Soon, researchers observed that those who were in fact unemployed and had been migrating seasonally (although the group was relatively smaller from those who were inactive on the labor market or took vacation to go and work abroad), were less likely to actively search for employment in Poland. There is also evidence that some individuals decided to focus entirely on seasonal employment and gave up their employment in Poland as not as rewarding in economic terms as work abroad 
(Fihel, 2004). Seasonal employment in Germany has therefore become a sole source of income for some families (Okólski, 2004b, p. 211).

The scarce possibilities of work in some (especially rural) regions, and the recognition that some groups of the population had special difficulties in the labor market overall (i.e. women in their fifties, who worked most of their life for one company during the socialist period) contributed largely to the preservation of this migration pattern in some regions. The problem, however, is that, besides money, this employment does not allow for the betterment of one's qualifications, allowing for more sustainable economic and/or social activity in local communities in Poland. Being on the margins of the German labor market for many workers, especially those who had been inactive on the Polish labor market, could mean further social and economic marginalization (Kaczmarczyk and Łukowski, 2004), especially related to their working life and prospects for career development in Poland (Jaźwińska-Motylska and Okólski, 2001).

Less tangible, however not less important, are the outcomes of this mobility on family life. As was proved in the literature on Polish seasonal migration, the pioneers were usually men, mostly from small- and medium-sized towns and villages in Poland (JaźwińskaMotylska and Okólski, 2001). However, over the course of time, this migration has became more feminized, which calls for more attention to gender issues and its relevance for the perpetuation of migration practices in relation to informal social protection practices. Many studies have proved that migration networks of women consist often of members of a familial network, which is related to the exertion of social control over women (Curran and Saguy, 2001; de Jong, Richter and Isarabhakdi, 1996). Moreover, migration changes the situation within the family, which can affect consecutive migration decisions, and in turn affect the power dynamics within the family (to name a few viable possibilities such as intra-familial exploitation, marginalization or emancipation). Hence, the case of female circular migrants proved that for some of them migration was a moment of liberation from the strict confines of gender roles at their local communities. Some may have felt more empowered as work abroad was their first moment of paid employment. Some female migrants even stated that despite physical and exhausting work this was a moment of "rest" for them from the family business and obligations that are constantly upon them in the family home ${ }^{6}$. Moreover, women more than men can migrate when their responsibilities regarding other family members and the household are taken care of, therefore issues regarding child rearing or taking care of elderly parents are of special importance.

\section{CONCLUSIONS}

Despite the fact that all European labor markets are now open for Polish nationals, the popularity of seasonal migration to Germany is still high. This is so especially in the rural and provincial areas where work opportunities are scarce, as they were in the beginning of the 1990s when the transition from one political system to another caused massive unemployment. Seasonal migration, accompanied by temporary work in services such as care or cleaning industries seems still to be an appealing option for several thousand Poles. In the course of more than two decades the gap between earnings in Poland and Germany narrowed and the cost of living in Poland has risen, therefore the economic rationale is not as attractive as it was previously. As the concept of cumulative causation (Massey, 1990) suggests, migration, once started, changes its initial conditions, eventually causing more migration - the reasons for the perpetuation of seasonal migration do not lie solely in their economic benefits for otherwise jobless or poorly paid beneficiaries (see above).

Most of the time, circular migration determines the nature of employment - large part of the job opportunities for Polish migrants were in the so-called low-wage sector and these were at least until 2011 agricultural harvest work, seasonal work in restaurants, activities in the care sector and services such as cleaning. These often meant that low income and low social status were combined in the country of destination. Constructed in this way, inequalities can be considered on many levels - family, migration network or between countries. The latter is objectified in bilateral agreements, which are interrelated with power imbalances between certain countries and thus reproducing inequalities on the agent level, limiting scopes of action. For example, when not allowing migrants to work legally in other sectors of the labor market. Consequently, migrants from respective emigration contexts are faced with limited chances for social upward mobility in the receiving community, when constrained to work in the secondary labor market. Not only does this represent an interesting insight into how, in this case, seasonal migration affects the people involved. Also, routinization of this migration strategy has had a tremendous impact on the family and local life of those involved in this mobility, which still calls for more attention, especially in the light of recent developments on the migration scene in this part of Europe. 


\section{NOTES}

[1] "Seasonal migration as everyday practice. Socio-cultural effects of seasonal migration for local societies: Case studies of Poland and Germany" realised in 2009-2011 during which we conducted fieldwork among seasonal workers. The project was financed by the GermanPolish Foundation for Science.

[2] On $16^{\text {th }}$ January 1991 the European Agreement establishing an association between the European Communities and their Member States and the Republic of Poland was signed. It was not a direct Polish-German agreement, but it maintained in force the existing agreements regarding access to the labor market established earlier under bilateral treaties.

[3] „Z woli obydwu stron sprawie budowania jedności europejskiej służyć będa

\section{REFERENCES}

Becker, J. (2010). Erdbeerpflücker, Spargelstecher, Erntehelfer: polnische Saisonarbeiter Deutschland-temporäre Arbeitsmigration im neuen Europa. Bielefeld: Transcript Verlag. http://dx.doi. org/10.14361/9783839409466

Curran, S. R. and Saguy, A. C. (2001). Migration and Cultural Change: A Role for Gender and Social Networks? Journal of International Women's Studies, 2, 3, pp. 54-77.

de Jong, G. F., Richter, K. and Isarabhakdi, P. (1996). Gender, Values, and Intentions to Move in Rural Thailand. International Migration Review, 30, 3, pp. 748-770. http://dx.doi.org/10.2307/2547635

Fiałkowska K. (2013). Gruppenbildung zwischen Klatsch und Neid. In Wagner, M., Fiałkowska K., Piechowska, M. and Łukowski, W. Deutsches Waschpulver und polnische Wirtschaft: Die Lebenswelt polnischer Saisonarbeiter. Ethnographische Beobachtunge. Bielefeld: Transcript Verlag, pp. 87-109. http://dx.doi.org/10.14361/transcript.9783839423332.87

Fiałkowska K. and Wagner, M. (2013). Polen und Deutsche - idealisiert und diskriminiert. In Wagner, M., Fiałkowska K., Piechowska, M. and Łukowski, W. Deutsches Waschpulver und polnische Wirtschaft Die Lebenswelt polnischer Saisonarbeiter. Ethnographische Beobachtunge. trwałe możliwości zatrudnienia Polaków w republice Federalnej Niemiec i Niemców w Rzeczypospolitej Polskiej.

W możliwościach tych upatrujemy się również źródła wzajemnie korzystnej i partnerskiej współpracy gospodarczej.

Uważamy, że nowe możliwości zatrudnienia sprzyjać będq wymienia gospodarczej oraz stanq się naturalnym $i$ trwałym zjawiskiem nowego ładu ekonomicznego w Europie $i$ wzajemnych stosunków.

Ze wspólnej pracy Polaków i Niemców uczynić możemy jednq z dróg do wzajemnego zbliżenia, doskonalenia wiedzy zawodowej, nauki języka oraz poznania krajów i ludzi.".

Bielefeld: Transcript Verlag, pp. 111 121. http://dx.doi.org/10.14361/transcript. 9783839423332.111

Fihel, A. (2004). Aktywność ekonomiczna migrantów sezonowych na polskim rynku pracy. In Kaczmarczyk, P. and Łukowski, W. (eds.), Polscy pracownicy na rynku Unii Europejskiej. Warszawa: Wydawnictwo Naukowe Scholar, pp. 115-128.

Jaźwińska-Motylska, E. and Okólski, M. (2001). Ludzie na huśtawce: migracje między peryferiami Polski i Zachodu. Warszawa: Wydawnictwo Naukowe Scholar.

Kaczmarczyk, P. (2005). Migracje zarobkowe Polaków $w$ dobie przemian. Warszawa: Wydawnictwa Uniwersytetu Warszawskiego.

Kaczmarczyk, P. and Łukowski, W. (eds.). (2004). Polscy pracownicy na rynku Unii Europejskiej). Warszawa: Wydawnictwo Naukowe Scholar.

Karczemski, M. and Boer, A. (2011). 'The Dutch Case': Networks of Polish Migrants in The Hague. In Stenning, A. and Słowik, A. (eds.). Post-Accession Migration in Europe - a Polish Case Study. Kraków: Impuls. pp. 75-90.

Kępińska, E. (2008). Migracje sezonowe z Polski do Niemiec : mechanizmy rekrutacji, rola rodziny i zróżnicowanie
[4] The agreement of 1990 effectively functioned since 1991 till January the 1st, 2011 - this date is the end of restrictions for Polish seasonal workers in accessing the labor market in Germany, and as of 1st of May, 2011, the restrictions were waived for all categories of workers.

[5] It is important to note that during the picking season workers usually do not have days off - such as in the case of a strawberry plantation where harvesting must be done promptly, because the fruits are very delicate.

[6] Issues related to liberation from family life were frequently mentioned, especially by women taking part in the research "Seasonal migration as everyday practice (...)".

według płci. Warszawa: Wydawnictwa Uniwersytetu Warszawskiego. http:// dx.doi.org/10.1016/j.iref.2013.05.003

Kępińska, E. and Stark, O. (2013). The evolution and sustainability of seasonal migration from Poland to Germany: From the dusk of the 19th century to the dawn of the 21st century. International Review of Economics and Finance, 28, pp. 3-18.

Kicinger, A. (2005). Polityka emigracyjna Il Rzeczpospolitej. Warszawa: Środkowoeuropejskie Forum Badań Migracyjnych.

Korczyńska, J. (2003). Sezonowe wyjazdy zarobkowe Polaków do Niemiec. Warszawa: Wydawnictwo Naukowe Scholar.

Landau, L. (1966). Wychodźstwo sezonowe na Łotwę i do Niemiec w 1937 roku: na podstawie ankiety Instytutu Gospodarstwa Społecznego. Warszawa: Książka i Wiedza.

Marek, E. (2008). Praca Polaków w Niemczech. Póltora wieku emigracji zarobkowej. Warszawa: IPiSS.

Massey, D. S. (1990). Social Structure, Household Strategies, and the Cumulative Causation of Migration. Population Index, 56, 1, pp. 3-26. http://dx.doi. org/10.2307/3644186 
Menz, G. K. (2001). Beyond the Anwerbestopp? The German-Polish Bilateral Labour Treaty. Journal of European Social Policy, 11, 3, pp. 253-269. http://dx.doi. org/10.1177/095892870101100304

Morokvasic, M. (2004). 'Settled in mobility': engendering post-wall migration in Europe. Feminist Review, 77, 1, pp. 7-25. http://dx.doi.org/10.1057/palgrave.fr.9400154

Napierała, J. and Fiałkowska, K. (2012). Mapping the market for employment agencies in Poland. Research report. Warsaw: Centre of Migration Research.

Okólski, M. (2004a). Przepływ siły roboczej w świetle niemiecko-polskiej umowy dwustronnej o pracownikach sezonowych. In Kaczmarczyk, P. and Łukowski, W. (eds.). Polscy pracownicy na rynku Unii Europejskiej. Warszawa: Wydawnictwo Naukowe Scholar, pp. 23-37.
Okólski, M. (2004b). Seasonal labor migration in the light of the German-Polish bilateral agreement. In O. f. E. C.-o. a. Development (ed.), Migration for employment: bilateral agreements at a crossroads. Paris: OECD.

Piechowska M. (2013). Als Soziologin auf dem Erdbeerfeld. In Wagner, M., Fiałkowska K., Piechowska, M. and Łukowski, W. Deutsches Waschpulver und polnische Wirtschaft: Die Lebenswelt polnischer Saisonarbeiter. Ethnographische Beobachtungen. Bielefeld: Transcript Verlag, pp. 2145. http://dx.doi.org/10.14361/transcript.9783839423332.21

Piechowska M. and Fiałkowska K (2013). Erntehelfer in der Tradition der "Sachsengänger". In Wagner M., Fiałkowska K., Piechowska, M. and Łukowski, W. Deutsches Waschpulver und polnische Wirtschaft: Die Lebenswelt polnischer Saisonarbeiter. Ethnographische Beobachtungen. Bielefeld: Transcript Verlag, pp. 165-182. http://dx.doi.org/10.14361/transcript.9783839423332.165

Rajkiewicz, A. (2000). Bilateralne uzgodnienia międzynarodowe a skala i struktura migracji zarobkowych. Polityka Społeczna, 5/6, pp. 32-35.

Stola, D. (2010). Kraj bez wyjścia? Migracje z Polski 1949-1989. Warszawa: Instytut Pamięci Narodowej - Komisja Ścigania Zbrodni przeciwko Narodowi Polskiemu.

Wagner, M., Fiałkowska, K., Piechowska, M. and Łukowski, W. (2013). Deutsches Waschpulver und polnische Wirtschaft. Die Lebenswelt polnischer Saisonarbeiter. Ethnographische Beobachtungen. Bielefeld: Transcript Verlag. 